\title{
Generation Means Analysis of Leaf and Stem Resistance to Gummy Stem Blight in Cucumber
}

\author{
Paul C. St. Amand ${ }^{1}$ and Todd C. Wehner ${ }^{2}$ \\ Department of Horticultural Science, North Carolina State University, Raleigh, NC 27695-7609
}

\begin{abstract}
AdDITIONAL INDEX words. Cucumis sativus, Cucurbitaceae, Didymella bryoniae, disease resistance, Phoma cucurbitacearum, vegetable breeding

Abstract. Leaf and stem resistance to gummy stem blight [Didymella bryoniae (Auersw.) Rehm.] in five resistant by susceptible crosses of cucumber (Cucumis sativus L.) was investigated using generation means analysis. No single gene of major effect controls either leaf or stem resistance to gummy stem blight in these five crosses. The mean number of effective factors controlling leaf resistance in the cross 'Slice' $x$ 'Wis. SMR 18' was estimated to be at least five. Estimates of broadand narrow-sense heritabilities indicated that environmental effects were larger than genetic effects. In general, additive variance was the larger component of genetic variance. Epistasis was significant in most crosses, and dominance was present in several crosses. Additive gene effects contributed more to resistance than to susceptibility in contrast with dominance gene effects. Reciprocal differences for leaf rating were detected in the crosses M 17 x 'Wis. SMR 18' and 'Slice' $x$ 'Wis. SMR 18'. Phenotypic correlations between leaf and stem ratings were moderate $(r=0.52$ to 0.72$)$. Estimates of genetic gain for resistance to gummy stem blight ranged from low to moderate. Breeding methods that make best use of additive variance should be used because much of the variance for resistance is additive, and dominance effects, at least in these crosses, tended to contribute to susceptibility.
\end{abstract}

Gummy stem blight causes severe defoliation and stem necrosis in the late stages of cucumber production. It is the second most important cucumber (Cucumis sativus) disease in North Carolina (St. Amand and Wehner, 1991), and is a serious disease of greenhouse cucumbers in The Netherlands, where it causes fruit rot (Van Steekelenburg, 1982). Gummy stem blight of cucumber is caused by Didymella bryoniae (Auersw.) Rehm (synonyms: Mycosphaerella citrullina (C. O. Sm.) Gross., and Mycosphaerella melonis (Pass.) Chiu and Walker) and its anamorph Phoma cucurbitacearum (Fr.:Fr.) Sacc. (Farr et al., 1989) (synonyms: Ascochyta cucumis Fautr. and Roum., and Phyllosticta cucurbitacearum Sacc.).

Several cultigens (breeding lines, cultivars, and plant introductions) resistant to gummy stem blight have been reported. Using field screening methods in Wisconsin, 'Homegreen \#2' and PI 200818 were reported to be resistant (Wyszogrodzka et al., 1986). In The Netherlands, greenhouse screening methods were used to identify several plant introduction accessions as resistant, including PI 200818 (Van Der Meer et al., 1978). In North Carolina, PI 164433, 'Slice', PI 390264, M 17 and M 12 were reported resistant using field screening methods (Wehner and St. Amand, 1993).

Wyszogrodzka et al. (1986) reported that the realized heritability for foliar resistance in one cycle of mass selection within 'Homegreen \#2' was 0.14 to 0.35 . However, a comprehensive assessment of the inheritance of resistance in cucumber has not been reported. Knowledge of the genetic basis and heritability of resistance to Didymella bryoniae is essential for efficient development of resistant cultivars. Thus, a study was designed to determine the types of gene action controlling foliar and stem resistance, estimate the genetic and environmental components of variance, estimate heritability and gain from selection, estimate the minimum number

Received for publication 18 May 1998. Accepted for publication 22 Aug. 2000. Research was supported in part by a grant from the North Carolina Pickle Producers Assoc., Mount Olive, NC 28365. We gratefully acknowledge technical assistance of R.R. Horton, Jr. The cost of publishing this paper was defrayed in part by the payment of page charges. Under postal regulations, this paper therefore must be hereby marked advertisement solely to indicate this fact.

${ }^{1}$ Former graduate research assistant. Currently assistant professor, Department of Agronomy, Kansas State University, Manhattan KS 66506.

${ }^{2}$ Professor; to whom reprint requests should be addressed. of effective factors controlling resistance, and investigate the effects of cytoplasmic inheritance on resistance.

\section{Materials and Methods}

Plant material. Parents were selected based on their diversity and previously reported levels of resistance. Resistant cucumber parents used were: PI 200818, 'Homegreen \#2', NCSU M 17, and 'Slice'. Susceptible parents used were: 'Wisconsin SMR 18' and 'Marketmore 76'. NCSUM 17, 'Slice', 'Wis. SMR 18', and 'Marketmore 76' are highly inbred lines. Seeds of PI 200818 and the open-pollinated 'Homegreen \#2' used in this study were self-pollinated and selected for resistance for five generations before use. M 17 and 'Wis. SMR 18' are pickling types; 'Homegreen \#2', 'Slice' and 'Marketmore 76' are slicing types; and PI 200818 is an accession from Burma.

Crosses and generations. Crosses were made between resistant and susceptible parents as follows: PI 200818 x 'Wis. SMR 18', 'Homegreen \#2' $x$ 'Wis. SMR 18', 'Homegreen \#2' $x$ 'Marketmore 76', M 17 x 'Wis. SMR 18', and 'Slice' $x$ 'Wis. SMR 18'. Generation means analysis was performed using each resistant $\left(\mathrm{P}_{1}\right)$ and susceptible parent $\left(\mathrm{P}_{2}\right), \mathrm{F}_{1}$ and $\mathrm{F}_{2}$ generations including reciprocals $\left(F_{1}{ }^{\prime}\right.$ and $\left.F_{2}{ }^{\prime}\right)$, and backcrosses of the $F_{1}$ to each parent $\left(\mathrm{B}_{1}\right.$ and $\left.\mathrm{B}_{2}\right)$. All crosses were controlled pollinations in a greenhouse.

INOCULUM PREPARATION AND APPLICATION. One virulent, single spore isolate of D. bryoniae (DB-H-23) collected from a diseased cucumber in North Carolina, was increased in petri plates containing $10 \mathrm{~mL}$ of cucumber malt extract agar (CMEA), using mycelial plug inoculation. The CMEA was prepared by tindalizing a purée of whole freshly harvested cucumber fruits and using the purée in place of one third of the water needed for standard malt extract agar (Difco, Detroit, Michigan, USA). Inoculated plates were then incubated for 10 to $14 \mathrm{~d}$ at $24^{\circ} \mathrm{C} \pm 2{ }^{\circ} \mathrm{C}$, with a $12 \mathrm{~h}$ photoperiod. The florescent lamps provided $\approx 40$ to $90 \mu \mathrm{mol} \cdot \mathrm{m}^{-2} \cdot \mathrm{s}^{-1} \mathrm{PPFD}$ at the upper surface of the plates. These culture conditions promoted formation of spore-producing pycnidia. Inoculum was prepared by flooding plates with 5 to $10 \mathrm{~mL}$ of acidified sterile distilled water and scraping the surface of the agar with a rubber spatula. The solution was 
acidified using concentrated lactic acid to a pH of 3.5 to 4.5 and also contained 20 drops/L Tween-80, a surfactant. The low $\mathrm{pH}$ and the surfactant increased spore discharge from pycnidia and greatly reduced spore agglutination. The liquid from each plate was filtered through four layers of cheesecloth to remove mycelium, pycnidia, and dislodged agar. The spore suspension was standardized to a concentration of $\approx 1 \times 10^{6}$ spores $/ \mathrm{mL}$ using a hemacytometer. The final $\mathrm{pH}$ of the inoculum was unadjusted and ranged from $\mathrm{pH} 5.4$ to 6.8 . The inoculum was maintained in the dark at $5{ }^{\circ} \mathrm{C}$ for $\approx 15 \mathrm{~h}$ until use. Svedelius and Unestam (1978) reported increased infectivity when plants were first sprayed with casein hydrolysate and sucrose. Therefore, immediately prior to inoculation, Tween-80 (10 drops/L), casein hydrolysate $(0.05 \%$ w/v, Sigma Chem.), and sucrose or dextrose $(0.1 \%$ w/v, Sigma Chem., St. Louis, Mo.) were added to the inoculum.

Plants were sprayed nearly to runoff at the vine-tip-over stage (four to six true leaves) 3 weeks after planting using a backpack sprayer (Solo, Sindelfingen, Germany) at 100 to $140 \mathrm{kPa}$ (15 to $20 \mathrm{psi}$ ). Inoculation was completed within $2 \mathrm{~h}$ after sunrise, before guttation exudates had dried from the leaves. Overhead irrigation was used ( 25 to $40 \mathrm{~mm}$ ) on the day prior to inoculation and $3 \mathrm{~d}$ after inoculation to encourage uniform disease development and spread the inoculum. Every fourth row was planted with susceptible 'Wis. SMR 18' to enhance uniformity of disease spread.

EXPERIMENTAL DESIGN AND DATA ANALYSIS. Field tests were conducted at the Horticultural Crops Research Station, Clinton, N.C. Plots were $3 \mathrm{~m}$ long and were planted on raised, shaped beds $1.5 \mathrm{~m}$ apart (center to center) separated at each end by $1 \mathrm{~m}$ alleys. Guard rows of susceptible 'Wis. SMR 18' surrounded each test. Standard cultural practices were used for crop production(Hughes et al., 1983). Field plots with 15 plants each were arranged in two randomized blocks with unequal numbers of plots for each generation. Parent, $F_{1}$, and $F_{1}{ }^{\prime}$ generations were each planted in one plot per block. Backcross generations $\left(\mathrm{B}_{1}\right.$ and $\left.\mathrm{B}_{2}\right)$ were each planted in two plots per block, $\mathrm{F}_{2}$ and $\mathrm{F}_{2}{ }^{\prime}$ were each planted in five plots per block. The test was planted 8 July 1991 and repeated 6 July 1992. Individual plants were rated 2 weeks after inoculation for foliar and stem lesions both years using a linear 0 to 9 scale (0 $=$ no symptoms and $9=100 \%$ necrosis) indicating the average degree of necrosis on all leaves, or the average degree of necrosis, cankers, and exudates on all stems. Each increase of the scale is equal to $\approx 11.1 \%$ more necrotic area.

Analysis of variance using GLM procedures of SAS (SAS Inst., Inc., Cary, N.C.) indicated that year and replication effects were nonsignificant, and transforming the data by log, square root, or arcsin had no effect on the additivity of the scale or distribution of the data. Therefore, generation means analysis was conducted without adjusting the data for year and replication effects or for scale effects. Phenotypic correlations between leaf and stem resistance were calculated using the CORR procedure of SAS. Midparent heterosis was estimated for individual crosses as the percentage deviation of the mean $F_{1}$ value from the midparent value. Differences between means and mean pairs were tested using single degree of freedom contrasts. Additive $\left(\sigma_{A}^{2}\right)$ and dominance $\left(\sigma_{D}^{2}\right.$ or nonadditive $)$ genetic variances and narrow-sense heritability $\mathrm{h}^{2}$ were estimated by the method of Warner (1952). Environmental variance was estimated as $\sigma_{\mathrm{E}}^{2}=$ $\left(\sigma_{\mathrm{P} 1}^{2}+\sigma_{\mathrm{P} 2}^{2}+2 \sigma_{\mathrm{F} 1}^{2}\right) / 4$ (Wright, 1968). Broad-sense heritability was estimated as $H=\left(\sigma_{\mathrm{F} 2}^{2}-\sigma_{\mathrm{E}}^{2}\right) / \sigma_{\mathrm{F} 2}^{2}$. Gene effects based on a six parameter model were estimated using the nonweighted method and notation described by Gamble (1962) and are defined as follows:

$$
\begin{aligned}
& \mathrm{m}=\mathrm{F}_{2} \\
& \mathrm{a}=+\mathrm{B}_{1}-\mathrm{B}_{2} \\
& \mathrm{~d}=-0.5 \mathrm{P}_{1}-0.5 \mathrm{P}_{2}+\mathrm{F}_{1}-4 \mathrm{~F}_{2}+2 \mathrm{~B}_{1}+2 \mathrm{~B}_{2} \\
& \mathrm{a}=-4 \mathrm{~F}_{2}+2 \mathrm{~B}_{1}+2 \mathrm{~B}_{2} \\
& \mathrm{ad}=-0.5 \mathrm{P}_{1}+0.5 \mathrm{P}_{2}+\mathrm{B}_{1}-\mathrm{B}_{2} \\
& \mathrm{dd}=\mathrm{P}_{1}+\mathrm{P}_{2}+2 \mathrm{~F}_{1}+4 \mathrm{~F}_{2}-4 \mathrm{~B}_{1}-4 \mathrm{~B}_{2}
\end{aligned}
$$

The number of effective factors controlling resistance was estimated by five methods. Method 1 was proposed by Wright (1968), method 2 was proposed by Mather and Jinks (1982), and methods 3 to 5 were proposed by Lande (1981). All of the effective factor formulas assume that segregating genes for resistance are all located in one parent, resistance genes are not linked, all resistance genes have equal effects on resistance, epistatic effects are absent, dominance effects are absent, and genotype $\times$ environment effects are absent (Wright, 1968).

\section{Results}

Parent and progeny means. Means and their ses for parental, $\mathrm{F}_{1}, \mathrm{~F}_{2}$, reciprocals, and backcross generations for leaf resistance are listed in Table 1 and for stem resistance in Table 2. The most resistant parent for leaf rating was 'Slice', followed by 'Homegreen \#2'. PI 200818 and M 17 were intermediate to resistant. Both 'Wis. SMR 18' and 'Marketmore 76' were very susceptible for both leaf and stem ratings. Since all $F_{2}$ and backcross generations had normal or only slightly skewed distributions without the presence of distinct bimodal peaks, chisquare tests were not performed. Heterosis for leaf and stem resistance was positive (toward the susceptible parent) or near zero for all crosses, except for stem resistance in the crosses 'Homegreen \#2' $x$ 'Marketmore 76' (-35\%) and M $17 \mathrm{x}$ 'Wis. SMR 18' $(-14 \%)$. Pooled means of the $F_{1}$ and $F_{1}^{\prime}\left(F_{1 P}\right)$ were not significantly different from pooled means of the $\mathrm{F}_{2}$ and $\mathrm{F}_{2}{ }^{\prime}\left(\mathrm{F}_{2 \mathrm{P}}\right)$ for leaf or stem rating in three crosses (PI $200818 \mathrm{x}$ 'Wis. SMR 18', 'Homegreen \#2' $x$ 'Marketmore 76', and M 17 x 'Wis. SMR $18^{\prime}$ ') as tested by single degree of freedom contrasts (Tables 1 and $2)$. In the cross 'Homegreen \#2' $x$ 'Wis. SMR 18', the $F_{2 P}$ mean was significantly different from the $F_{1 P}$ and was shifted toward the susceptible parent for both leaf and stem ratings. In the cross 'Slice' $\mathrm{X}$ 'Wis. SMR 18', the $\mathrm{F}_{2 \mathrm{P}}$ mean was significantly different from the $F_{1 P}$ and was shifted toward the resistant parent for both leaf and stem ratings. No cross produced significant transgressive segregant progeny.

Cytoplasmic EFfects. No significant differences were found between $\mathrm{F}_{1}\left(\mathrm{P}_{1} \times \mathrm{P}_{2}\right)$ and $\mathrm{F}_{1}{ }^{\prime}\left(\mathrm{P}_{2} \times \mathrm{P}_{1}\right)$ or between $\mathrm{F}_{2}\left(\mathrm{~F}_{1} \times \mathrm{F}_{1}\right)$ and $\mathrm{F}_{2}^{\prime}\left(\mathrm{F}_{1}^{\prime} \times \mathrm{F}_{1}^{\prime}\right)$ for crosses PI $200818 \times$ 'Wis. SMR 18' and 'Homegreen \#2' $x$ 'Wis. SMR 18' for either leaf or stem ratings (Tables 1 and 2). Crosses M 17 x 'Wis. SMR 18' and 'Slice' $x$ 'Wis. SMR 18' however, had highly significant $(P=0.0044$ to $0.0001)$ differences between reciprocals in both $F_{1}$ and $F_{2}$ generations with differences ranging from 0.7 to 1.3 rating scale units ( $8 \%$ to $14 \%$ of the total rating scale) for leaf and stem ratings. The $\mathrm{F}_{1}$ and $\mathrm{F}_{2}$ were more resistant than their reciprocals in the $\mathrm{M} 17 \mathrm{X}$ 'Wis. SMR 18' cross, but the $\mathrm{F}_{1}$ ' and $\mathrm{F}_{2}$ ' were more resistant in the 'Slice' $x$ 'Wis. SMR 18' cross. In the 'Homegreen \#2' $x$ 'Marketmore 76' cross, the occurrence and direction of reciprocal differences varied between generations and between leaf and stem ratings (Tables 1 and 2 ). The $\mathrm{F}_{1}$ and $\mathrm{F}_{1}{ }_{1}$ differed in leaf ratings by 0.8 rating scale units $(P=0.0162)$, but the $F_{2}$ and $F_{2}^{\prime}$ were not significantly different. However, for stem ratings in the same cross, the $\mathrm{F}_{2}$ and $\mathrm{F}_{2}{ }^{\prime}$ differed by 1.3 rating scale units $(P=0.0053)$, but the $F_{1}$ and $F_{1}{ }^{\prime}$ were not significantly different. 
Table 1. Leaf rating means (number plants tested) \pm SE for resistance to gummy stem blight in cucumber for parent and offspring populations from five crosses. Rating is from 0 (no disease symptoms) to 9 (complete leaf necrosis). Means are from two replications each year in 1991 and 1992. Resistant and susceptible parents indicated by $(\mathrm{R})$ and $(\mathrm{S})$ respectively.

\begin{tabular}{|c|c|c|c|c|c|}
\hline \multirow[b]{4}{*}{ Population $^{\mathrm{Z}}$} & \multicolumn{5}{|c|}{ Parents of cross } \\
\hline & PI 200818 (R) & 'Homegreen \#2' (R) & 'Homegreen \#2' (R) & M $17(\mathrm{R})$ & 'Slice' (R) \\
\hline & $\mathrm{x}$ & $\mathrm{x}$ & $\mathrm{x}$ & $\mathrm{x}$ & $\mathrm{x}$ \\
\hline & 'Wis. SMR 18' (S) & 'Wis. SMR 18' (S) & 'Marketmore 76' (S) & 'Wis. SMR 18' (S) & 'Wis. SMR 18' (S) \\
\hline \multicolumn{6}{|c|}{ Contrasts among generations } \\
\hline $\mathrm{P}_{1}$ & $4.3 \pm 0.3^{y}(29) c^{y}$ & $3.4 \pm 0.1(44) c$ & $3.4 \pm 0.1(44) \mathrm{d}$ & $4.9 \pm 0.4(32) c$ & $2.2 \pm 0.2(35) \mathrm{e}$ \\
\hline $\mathrm{B}_{1}$ & $6.1 \pm 0.3(59) \mathrm{a}$ & $5.1 \pm 0.2(68) b$ & $2.5 \pm 0.3(14) \mathrm{e}$ & $4.7 \pm 0.2(106) c$ & $3.7 \pm 0.2(75) \mathrm{d}$ \\
\hline $\mathrm{F}_{1 \mathrm{p}}$ & $6.0 \pm 0.2(59) \mathrm{ab}$ & $5.2 \pm 0.2(61) b$ & $5.3 \pm 0.2(76) \mathrm{c}$ & $5.5 \pm 0.1(73) b$ & $5.4 \pm 0.2(74) b$ \\
\hline$F_{2 p}^{1 p}$ & $5.6 \pm 0.1(223) b$ & $5.8 \pm 0.1(227) \mathrm{a}$ & $5.3 \pm 0.1(147) \mathrm{c}$ & $5.5 \pm 0.1(313) b$ & $4.4 \pm 0.1(165) \mathrm{c}$ \\
\hline $\mathrm{B}_{2}^{2 \mathrm{p}}$ & $5.8 \pm 0.1(93) a b$ & $5.8 \pm 0.2(88) \mathrm{a}$ & $5.8 \pm 0.2(64) b$ & $5.5 \pm 0.2(81) b$ & $5.7 \pm 0.1(104) a b$ \\
\hline $\mathrm{P}_{2}^{2}$ & $6.2 \pm 0.2(35) \mathrm{a}$ & $6.2 \pm 0.2(35) \mathrm{a}$ & $6.8 \pm 0.3(30) \mathrm{a}$ & $6.2 \pm 0.2(35) \mathrm{a}$ & $6.2 \pm 0.2(35) \mathrm{a}$ \\
\hline \multicolumn{6}{|c|}{ Contrasts among $\mathrm{F}_{1}$ and $\mathrm{F}_{1}{ }^{\prime}$} \\
\hline $\mathrm{F}_{1}$ & $5.8 \pm 0.3(25) \mathrm{a}$ & $4.8 \pm 0.2(33) \mathrm{a}$ & $4.9 \pm 0.2(39) b$ & $5.0 \pm 0.2(39) b$ & $6.1 \pm 0.2(31) \mathrm{a}$ \\
\hline $\mathrm{F}_{1}^{\prime}$ & $6.1 \pm 0.2(34) \mathrm{a}$ & $5.6 \pm 0.3(28) \mathrm{a}$ & $5.7 \pm 0.2(37) \mathrm{a}$ & $6.1 \pm 0.2(34) \mathrm{a}$ & $5.0 \pm 0.2(43) b$ \\
\hline \multicolumn{6}{|c|}{ Contrast among $\mathrm{F}_{2}$ and $\mathrm{F}_{2}{ }^{\prime}$} \\
\hline $\mathrm{F}_{2}$ & $5.4 \pm 0.1(112) a$ & $5.8 \pm 0.1(127) a$ & $5.4 \pm 0.2(69) \mathrm{a}$ & $5.2 \pm 0.1(182) b$ & $4.8 \pm 0.2(90) \mathrm{a}$ \\
\hline $\mathrm{F}_{2}^{\prime}$ & $5.8 \pm 0.1(111) a$ & $5.7 \pm 0.2(100) \mathrm{a}$ & $5.2 \pm 0.2(78) \mathrm{a}$ & $6.0 \pm 0.1(131) \mathrm{a}$ & $4.0 \pm 0.1(75) b$ \\
\hline
\end{tabular}

zPopulation notation (females listed first in each cross): $\mathrm{P}_{1}=$ (resistant parent); $\mathrm{P}_{2}=($ susceptible parent $) ; \mathrm{F}_{1}=\left(\mathrm{P}_{1} \times \mathrm{P}_{2}\right) ; \mathrm{F}_{1}{ }^{\prime}=\left(\mathrm{P}_{2} \times \mathrm{P}_{1}\right) ; \mathrm{B}_{1}=\left(\mathrm{F}_{1} \mathrm{X}\right.$ $\left.\mathrm{P}_{1}\right) ; \mathrm{B}_{2}=\left(\mathrm{F}_{1} \times \mathrm{P}_{2}\right) ; \mathrm{F}_{2}=\left(\mathrm{F}_{1} \times \mathrm{F}_{1}\right) ; \mathrm{F}_{2}{ }^{\prime}=\left(\mathrm{F}_{1}{ }^{\prime} \times \mathrm{F}_{1}{ }^{\prime}\right) ; \mathrm{F}_{1 \mathrm{p}}=\left(\mathrm{F}_{1}\right.$ pooled with $\left.\mathrm{F}_{1}{ }^{\prime}\right) ; \mathrm{F}_{2 \mathrm{p}}=\left(\mathrm{F}_{2}\right.$ pooled with $\left.\mathrm{F}_{2}{ }^{\prime}\right)$.

${ }^{\mathrm{y}}$ Within a cross and contrast group, means followed by the same letter are not significantly different at $P \leq 0.05$ based on single degree of freedom contrasts.

Phenotypic Correlations. The phenotypic correlation between leaf and stem ratings over all crosses and generations was moderate $(r=0.67, P=0.0001)$. Correlations within crosses were similar for all crosses ranging from $r=0.69$ to $r=0.72(P=0.0001)$, except for M 17 X 'Wis. SMR 18' which was $r=0.52(P=0.0001)$.

GENE EFFECTS. Geneeffects were estimated using the nonweighted method and notation of Gamble (1962) and are listed in Table 3. The midpoint ranged from 5.3 to 5.8 for all crosses for leaf rating, except for 'Slice' x 'Wis. SMR 18', which was significantly lower (4.4). The midpoint for stem rating varied with each cross. Additive (a), dominance (d), and additive $\times$ additive (aa) effects were nearly always negative (toward the resistant parent) for both leaf and stem ratings. Dominance $\times$ dominance $(\mathrm{dd})$ effects, where significant, were always positive (toward the susceptible parent) and had the greatest magnitude of any single effect for both leaf and stem ratings. However, positive dd effects were usually reduced by negative $d$ effects. Because of the opposite signs of $d$ and dd effects, the sums of the significant a + aa effects were usually of a greater magnitude than the sums of the significant $d+d d$ effects for both leaf and stem ratings. One form of epistasis, additive $\times$ dominance $(\mathrm{ad})$, was not

Table 2. Stem rating means (number plants tested) \pm SE for resistance to gummy stem blight in cucumber for parent and offspring populations from five crosses. Rating is from 0 (no disease symptoms) to 9 (complete stem necrosis). Means are from two replications each year in 1991 and 1992. Resistant and susceptible parents indicated by $(\mathrm{R})$ and $(\mathrm{S})$ respectively.

\begin{tabular}{|c|c|c|c|c|c|}
\hline \multirow[b]{4}{*}{ Population $^{z}$} & \multicolumn{5}{|c|}{ Parents of cross } \\
\hline & PI $200818(\mathrm{R})$ & 'Homegreen \#2' (R) & 'Homegreen \#2' (R) & M 17 (R) & ‘Slice’ (R) \\
\hline & $\mathrm{x}$ & $\mathrm{x}$ & $\mathrm{x}$ & $\mathrm{x}$ & $\mathrm{x}$ \\
\hline & 'Wis. SMR 18' (S) & ‘Wis. SMR 18’ (S) & 'Marketmore 76’ (S) & ‘Wis. SMR 18’ (S) & 'Wis. SMR 18' (S) \\
\hline \multicolumn{6}{|c|}{ Contrasts among generations } \\
\hline $\mathrm{P}_{1}$ & $4.7 \pm 0.3^{\mathrm{y}}(19) \mathrm{c}^{\mathrm{y}}$ & $1.3 \pm 0.1(27) \mathrm{e}$ & $1.3 \pm 0.1(27) \mathrm{d}$ & $3.1 \pm 0.3(22) \mathrm{c}$ & $1.5 \pm 0.2(26) \mathrm{f}$ \\
\hline $\mathrm{B}_{1}$ & $5.5 \pm 0.4(46) b$ & $4.1 \pm 0.3(50) \mathrm{d}$ & $1.5 \pm 0.3(8) \mathrm{d}$ & $3.1 \pm 0.2(86) \mathrm{c}$ & $2.7 \pm 0.2(58) \mathrm{e}$ \\
\hline $\mathrm{F}_{1 \mathrm{p}}$ & $6.1 \pm 0.2(40) \mathrm{ab}$ & $5.1 \pm 0.2(53) \mathrm{c}$ & $3.0 \pm 0.2(56) \mathrm{c}$ & $4.3 \pm 0.2(54) b$ & $4.5 \pm 0.2(54) c$ \\
\hline $\mathrm{F}_{2 \mathrm{p}}$ & $5.5 \pm 0.1(173) b$ & $5.7 \pm 0.2(181) b$ & $3.5 \pm 0.2(99) \mathrm{c}$ & $4.6 \pm 0.1(263) b$ & $3.8 \pm 0.2(102) \mathrm{d}$ \\
\hline $\mathrm{B}_{2}^{2 \mathrm{p}}$ & $5.6 \pm 0.2(74) b$ & $6.1 \pm 0.2(71) \mathrm{ab}$ & $4.4 \pm 0.3(47) b$ & $4.7 \pm 0.2(64) b$ & $5.3 \pm 0.2(86) b$ \\
\hline $\mathrm{P}_{2}^{2}$ & $6.8 \pm 0.3(13) \mathrm{a}$ & $6.8 \pm 0.3(13) \mathrm{a}$ & $7.6 \pm 0.2(23) \mathrm{a}$ & $6.8 \pm 0.3(13) \mathrm{a}$ & $6.8 \pm 0.3(13) \mathrm{a}$ \\
\hline \multicolumn{6}{|c|}{ Contrasts among $\mathrm{F}_{1}$ and $\mathrm{F}_{1}{ }^{\prime}$} \\
\hline $\mathrm{F}_{1}$ & $5.9 \pm 0.5(15) \mathrm{a}$ & $5.0 \pm 0.3(26) \mathrm{a}$ & $3.0 \pm 0.4(29) \mathrm{a}$ & $3.9 \pm 0.3(29) \mathrm{a}$ & $5.0 \pm 0.4(21) \mathrm{a}$ \\
\hline $\mathrm{F}_{1}^{\prime}$ & $6.2 \pm 0.3(25) \mathrm{a}$ & $5.2 \pm 0.4(27) \mathrm{a}$ & $2.9 \pm 0.3(27) \mathrm{a}$ & $4.6 \pm 0.2(25) \mathrm{a}$ & $4.2 \pm 0.3(33) \mathrm{a}$ \\
\hline \multicolumn{6}{|c|}{ Contrast among $\mathrm{F}_{2}$ and $\mathrm{F}_{2}{ }^{\prime}$} \\
\hline $\mathrm{F}_{2}$ & $5.2 \pm 0.3(62) \mathrm{a}$ & $5.9 \pm 0.2(81) \mathrm{a}$ & $4.5 \pm 0.6(21) \mathrm{a}$ & $4.1 \pm 0.2(132) b$ & $4.3 \pm 0.3(27) \mathrm{a}$ \\
\hline $\mathrm{F}_{2}^{\prime}$ & $5.6 \pm 0.2(111) \mathrm{a}$ & $5.5 \pm 0.2(100) \mathrm{a}$ & $3.2 \pm 0.2(78) b$ & $5.1 \pm 0.2(131) \mathrm{a}$ & $3.0 \pm 0.2(75) b$ \\
\hline
\end{tabular}

2Population notation (females listed first in each cross): $\mathrm{P}_{1}=\left(\right.$ resistant parent); $\mathrm{P}_{2}=($ susceptible parent $) ; \mathrm{F}_{1}=\left(\mathrm{P}_{1} \times \mathrm{P}_{2}\right) ; \mathrm{F}_{1}{ }^{\prime}=\left(\mathrm{P}_{2} \times \mathrm{P}_{1}\right) ; \mathrm{B}_{1}=\left(\mathrm{F}_{1} \times\right.$ $\left.\mathrm{P}_{1}\right) ; \mathrm{B}_{2}=\left(\mathrm{F}_{1} \times \mathrm{P}_{2}\right) ; \mathrm{F}_{2}=\left(\mathrm{F}_{1} \times \mathrm{F}_{1}\right) ; \mathrm{F}_{2}{ }^{\prime}=\left(\mathrm{F}_{1}{ }^{\prime} \times \mathrm{F}_{1}{ }^{\prime}\right) ; \mathrm{F}_{1 \mathrm{p}}=\left(\mathrm{F}_{1}\right.$ pooled with $\left.\mathrm{F}_{1}{ }^{\prime}\right) ; \mathrm{F}_{2 \mathrm{p}}{ }^{2}=\left(\mathrm{F}_{2}\right.$ pooled with $\left.\mathrm{F}_{2}{ }^{\prime}\right)$.

${ }^{y}$ Within a cross and contrast group, means followed by the same letter are not significantly different at $P \leq 0.05$ based on single degree of freedom contrasts. 
Table 3. Estimates of gene effects \pm SE for leaf and stem resistance to gummy stem blight in cucumber for five resistant (R) by susceptible (S) crosses from two replications each year in 1991 and 1992. Rating is from 0 (no disease symptoms) to 9 (complete leaf or stem necrosis). Estimates calculated using the method of Gamble (1962).

\begin{tabular}{|c|c|c|c|c|c|}
\hline \multirow[b]{4}{*}{ Effect } & \multicolumn{5}{|c|}{ Parents of cross } \\
\hline & PI 200818 (R) & 'Homegreen \#2' (R) & 'Homegreen \#2' (R) & M $17(\mathrm{R})$ & 'Slice' (R) \\
\hline & $\mathrm{x}$ & $\mathrm{x}$ & $x$ & $\mathrm{x}$ & $\mathrm{x}$ \\
\hline & 'Wis. SMR 18' (S) & 'Wis. SMR 18' (S) & 'Marketmore 76' (S) & 'Wis. SMR 18' (S) & 'Wis. SMR 18' (S) \\
\hline \multicolumn{6}{|c|}{ Leaf estimates } \\
\hline $\mathrm{m}$ & $5.6 \pm 0.1^{* *}$ & $5.8 \pm 0.1^{* * *}$ & $5.3 \pm 0.1^{* *}$ & $5.5 \pm 0.1^{* *}$ & $4.4 \pm 0.1^{* * *}$ \\
\hline $\mathrm{a}$ & $0.3 \pm 0.3$ & $-0.7 \pm 0.3^{* *}$ & $-3.3 \pm 0.3^{* *}$ & $-0.8 \pm 0.2^{* *}$ & $-2.0 \pm 0.2^{* *}$ \\
\hline $\mathrm{d}$ & $0.6 \pm 0.8$ & $1.4 \pm 0.7$ & $-4.4 \pm 0.9^{* *}$ & $-1.7 \pm 0.6^{* *}$ & $-1.7 \pm 0.7^{*}$ \\
\hline aa & $1.3 \pm 0.8$ & $-1.5 \pm 0.7^{*}$ & $-4.6 \pm 0.9^{* *}$ & $-1.7 \pm 0.6^{* *}$ & $1.1 \pm 0.7$ \\
\hline ad & $1.2 \pm 0.4^{* *}$ & $0.6 \pm 0.3^{*}$ & $-1.6 \pm 0.4^{* *}$ & $-0.2 \pm 0.3$ & $0.0 \pm 0.3$ \\
\hline dd & $-2.6 \pm 1.5$ & $-0.3 \pm 1.2$ & $8.8 \pm 1.5^{* *}$ & $3.4 \pm 1.1^{* * *}$ & $-0.7 \pm 1.1$ \\
\hline \multicolumn{6}{|c|}{ Stem estimates } \\
\hline $\mathrm{m}$ & $5.5 \pm 0.1^{z^{* *}}$ & $5.7 \pm 0.2^{* *}$ & $3.5 \pm 0.2^{* *}$ & $4.6 \pm 0.1^{* *}$ & $3.4 \pm 0.2^{* *}$ \\
\hline $\mathrm{a}$ & $-0.1 \pm 0.4$ & $-2.0 \pm 0.4^{* *}$ & $-2.9 \pm 0.4^{* *}$ & $-1.6 \pm 0.3^{* *}$ & $-2.6 \pm 0.3^{* *}$ \\
\hline $\mathrm{d}$ & $-1.3 \pm 1.1$ & $1.3 \pm 1.0$ & $-1.5 \pm 1.3$ & $-2.2 \pm 0.8^{* *}$ & $-1.6 \pm 1.0$ \\
\hline aa & $0.3 \pm 1.0$ & $-2.5 \pm 1.0^{*}$ & $-2.2 \pm 1.3$ & $-3.0 \pm 0.8^{* *}$ & $2.5 \pm 1.0^{*}$ \\
\hline ad & $0.4 \pm 0.5$ & $0.3 \pm 0.4$ & $0.3 \pm 0.5$ & $0.2 \pm 0.4$ & $0.1 \pm 0.4$ \\
\hline $\mathrm{dd}$ & $0.2 \pm 1.9$ & $-0.4 \pm 1.7$ & $5.3 \pm 2.1^{*}$ & $6.0 \pm 1.5^{* * *}$ & $-1.3 \pm 1.6$ \\
\hline
\end{tabular}

,*** Estimate significantly different from zero at $P=0.05$ or 0.01 , respectively.

significant for stem rating in any cross, and where significant for leaf rating, was usually of minor effect.

VARIANCE COMPONENTS AND HERITABILITY ESTIMATES. The environmental component of variance was larger than additive or dominance variance in four of the five crosses for leaf rating and in two of the five crosses for stem rating (Table 4). For both leaf and stem ratings, additive variance was larger than dominance variance in three crosses ('Homegreen \#2' x 'Wis. SMR 18', 'Homegreen \#2' $x$ 'Marketmore 76', and 'Slice' $x$ 'Wis. SMR 18'). Dominance variance was large only in the progeny of the PI $200818 \times$ 'Wis. SMR 18' cross. Estimates of the variance components varied considerably between crosses. Additive variance ranged from -3.0 to 5.2, and dominance variance ranged from -1.8 to 4.4 .

Heritabilities varied considerably between crosses (Table 4). Negative estimates were assumed to be zero (Robinson et al., 1955), but are reported as recommended by Dudley and Moll (1969) for future comparisons and were used in variance component estimates to avoid truncated sampling distributions (Gordon et al., 1972). Broad-sense heritabilities $(\mathrm{H})$ ranged from 0.0 to 0.66 , and narrowsense heritability $\left(\mathrm{h}^{2}\right)$ ranged from 0.0 to 1.02 . Genetic gain per cycle for selection at the $10 \%$ level $\left(G_{S}\right)$ was calculated as $G_{S}=(1.76)\left(h^{2}\right)$
$\left(\sigma_{\mathrm{F} 2}\right)$, and ranged up to 1.8 for leaf rating and 4.0 for stem rating. Estimates of gain were larger for those crosses with a larger difference between parents and were slightly larger for stem ratings.

EFFECTIVE FACTORS. Estimates of the minimum number of genes (effective factors) controlling leaf and stem resistance are presented in Table 5. Estimates ranged over all crosses from -3.1 to 10.3 for leaf rating, and from -0.1 to 7.1 for stem rating. Mean estimates for each cross ranged from -0.8 to 5.2 for leaf rating and from 0.0 to 3.3 for stem rating.

\section{Discussion}

No cross exhibited complete dominance or distinct bimodal distributions, suggesting that no single gene of major effect controls either leaf or stem resistance to gummy stem blight in these five crosses. Dominance and most types of epistasis will bias the estimate of effective factors downward (Wright, 1968). It is likely that estimates of the number of effective factors were highly biased (reduced) by the failure to meet the analysis assumptions of no epistasis and no dominance, because some dominance effects were present in several crosses and epistasis was significant in all crosses

Table 4. Estimates of additive $\left(\sigma_{A}^{2}\right)$, dominance $\left(\sigma_{D}^{2}\right)$, and environmental $\left(\sigma_{E}^{2}\right)$ variances, broad- $(H)$ and narrow- $\left(h^{2}\right)$ sense heritabilities, and genetic gain through selection (Gs) for leaf and stem resistance to gummy stem blight in five resistant by susceptible cucumber crosses from two replications each year in 1991 and 1992.

\begin{tabular}{|c|c|c|c|c|c|c|c|c|c|c|c|c|}
\hline \multirow[b]{2}{*}{ Cross } & \multicolumn{6}{|c|}{ Leaf rating } & \multicolumn{6}{|c|}{ Stem rating } \\
\hline & $\overline{\sigma_{A}^{2}}$ & $\sigma_{\mathrm{D}}^{2}$ & $\sigma_{E}^{2}$ & $\mathrm{H}^{\mathrm{y}}$ & $\mathrm{h}^{2}$ & $\mathrm{Gs}^{\mathrm{x}}$ & $\overline{\sigma_{\mathrm{A}}^{2}}$ & $\sigma_{\mathrm{D}}^{2}$ & $\sigma_{\mathrm{E}}^{2}$ & $\mathrm{H}$ & $\mathrm{h}^{2}$ & Gs \\
\hline PI $200818 \times$ Wis. SMR 18 & -3.0 & 3.4 & 1.8 & 0.20 & $0.0^{\mathrm{W}}$ & $0.0^{\mathrm{w}}$ & -3.1 & 4.4 & 2.0 & 0.44 & $0.0^{\mathrm{w}}$ & $0.0^{\mathrm{w}}$ \\
\hline Homegreen \#2 x Wis. SMR 18 & 0.8 & 0.5 & 1.7 & 0.44 & 0.27 & 0.8 & 2.1 & 0.6 & 1.9 & 0.58 & 0.45 & 1.7 \\
\hline Homegreen \#2 x Marketmore 76 & 1.6 & -1.0 & 2.0 & 0.23 & 0.63 & 1.8 & 5.2 & -1.8 & 1.7 & 0.66 & 1.02 & 4.0 \\
\hline M $17 \times$ Wis. SMR 18 & -0.6 & 0.2 & 2.5 & $0.0^{\mathrm{w}}$ & $0.0^{\mathrm{w}}$ & $0.0^{\mathrm{w}}$ & 0.7 & 1.2 & 1.8 & 0.52 & 0.19 & 0.7 \\
\hline Slice $\mathrm{x}$ Wis. SMR 18 & 0.8 & -0.3 & 1.9 & 0.21 & 0.34 & 0.9 & 1.0 & 0.7 & 2.2 & 0.44 & 0.26 & 0.9 \\
\hline
\end{tabular}


Table 5. Estimates of the minimum number of genes or effective factors (EF) controlling leaf and stem resistance to gummy stem blight in five resistant by susceptible cucumber crosses from two replications each year in 1991 and $1992 .^{\mathrm{z}}$

\begin{tabular}{|c|c|c|c|c|c|c|c|c|c|c|c|c|}
\hline \multirow[b]{2}{*}{ Cross } & \multicolumn{6}{|c|}{ Leaf rating } & \multicolumn{6}{|c|}{ Stem rating } \\
\hline & $\mathrm{EF}_{1}$ & $\mathrm{EF}_{2}$ & $\mathrm{EF}_{3}$ & $\mathrm{EF}_{4}$ & $\mathrm{EF}_{5}$ & Mean & $\mathrm{EF}_{1}$ & $\mathrm{EF}_{2}$ & $\mathrm{EF}_{3}$ & $\mathrm{EF}_{4}$ & $\mathrm{EF}_{5}$ & Mean \\
\hline PI 200818 x ‘Wis. SMR 18' & 1.3 & -0.3 & 1.0 & -0.1 & 0.1 & 0.4 & 0.2 & -0.1 & 0.1 & 0.0 & 0.0 & 0.0 \\
\hline 'Homegreen \#2' x 'Wis. SMR 18' & 0.7 & 2.2 & 0.7 & 1.1 & 0.5 & 1.0 & 1.2 & 2.5 & 0.9 & 1.2 & 0.8 & 1.3 \\
\hline 'Homegreen \#2' x 'Marketmore 76' & 2.3 & 1.7 & 2.3 & 0.8 & -3.1 & 0.8 & 1.7 & 1.9 & 1.5 & 1.0 & 3.2 & 1.9 \\
\hline M 17 x 'Wis. SMR 18' & -0.6 & -0.7 & -0.6 & -0.3 & -1.6 & -0.8 & 0.9 & 4.6 & 0.8 & 2.3 & 0.5 & 1.8 \\
\hline 'Slice' x 'Wis. SMR 18' & 4.6 & 4.8 & 3.9 & 2.4 & 10.3 & 5.2 & 2.1 & 7.1 & 2.1 & 3.5 & 1.5 & 3.3 \\
\hline
\end{tabular}

${ }^{\mathrm{Z}} \mathrm{EF}_{1}=\left(\mathrm{P}_{2}-\mathrm{P}_{1}\right)^{2}[1.5-2 \mathrm{~h}(1-\mathrm{h})] / 8\left[\sigma_{\mathrm{F} 2}^{2}-0.25\left(\sigma_{\mathrm{P} 1}^{2}+\sigma_{\mathrm{P} 2}^{2}+2 \sigma_{\mathrm{F} 1}^{2}\right)\right]$, where $\mathrm{h}=\mathrm{F}_{1}-\mathrm{P}_{1} / \mathrm{P}_{2}-\mathrm{P}_{1}$.

$\mathrm{EF}_{2}=\left[0.5\left(\mathrm{P}_{2}-\mathrm{P}_{1}\right)\right]^{2} /\left[2 \sigma_{\mathrm{F} 2}^{2}-\left(\sigma_{\mathrm{B} 1}^{2}+\sigma_{\mathrm{B} 2}^{2}\right)\right]$.

$\mathrm{EF}_{3}=\left(\mathrm{P}_{2}-\mathrm{P}_{1}\right)^{2} / 8\left[\sigma_{\mathrm{F} 2}^{2}-0.25\left(\sigma_{\mathrm{P} 1}^{2}+\sigma_{\mathrm{P} 2}^{2}+2 \sigma_{\mathrm{F} 1}^{2}\right)\right]$.

$\mathrm{EF}_{4}=\left(\mathrm{P}_{2}-\mathrm{P}_{1}\right)^{2} / 8\left[2 \sigma_{\mathrm{F} 2}^{2}-\left(\sigma_{\mathrm{B} 1}^{2}+\sigma_{\mathrm{B} 2}^{2}\right)\right]$.

$\mathrm{EF}_{5}=\left(\mathrm{P}_{2}-\mathrm{P}_{1}\right)^{2} / 8\left[\sigma_{\mathrm{B} 1}^{2}+\sigma_{\mathrm{B} 2}^{2}-\left(\sigma_{\mathrm{F} 1}^{2}+0.5 \sigma_{\mathrm{P} 1}^{2}+0.5 \sigma_{\mathrm{P} 2}^{2}\right)\right]$.

except in 'Slice' $x$ 'Wis. SMR 18' for leaf rating and in PI 200818 $\mathrm{X}$ 'Wis. SMR 18 ' for stem rating. In addition to lacking epistasis for leaf rating, the cross 'Slice' $x$ 'Wis. SMR 18' also had little dominance; therefore, estimates of the minimum number of effective factors for that cross are likely to be more accurate than the estimates from other crosses. The mean number of effective factors for 'Slice' $\mathrm{x}$ 'Wis. SMR 18' was estimated to be at least 5 for leaf ratings. If the resistance genes found in this cross are linked in coupling phase, the actual number of genes affecting leaf resistance could be much greater.

The generally low estimates of broad- and narrow-sense heritabilities indicate that the environment in which the plants are tested has a larger effect on leaf and stem rating than the genotype. This finding is in agreement with the low realized heritability ( 0.14 to 0.35 ) for mass selection in 'Homegreen \#2' reported by Wyszogrodzka et al. (1986). Breeding efforts to increase resistance will require good control over environmental variation. In general, additive variance was the largest component of genetic variance. Significant estimates of additive gene effects (a and aa) were usually negative, indicating that additive effects contribute more to resistance than to susceptibility, in contrast with significant estimates of dominance gene effects ( $\mathrm{d}$ and $\mathrm{dd}$ ) which were usually positive. The presence of epistasis was usually significant in all crosses; therefore, genetic models which assume no epistasis do not accurately describe leaf or stem resistance to gummy stem blight in cucumber.

Reciprocal differences consistent with cytoplasmic inheritance were detected in crosses M $17 \mathrm{x}$ 'Wis. SMR 18' and 'Slice' $\mathrm{x}$ 'Wis. SMR 18' for leaf rating. As a maternal parent, the resistant cultigen M 17 produced more resistant offspring than as a paternal parent in the M 17x 'Wis. SMR 18' cross; however, as a maternal parent, the resistant cultigen 'Slice' produced fewer resistant offspring than as a paternal parent in the 'Slice' $x$ 'Wis. SMR 18' cross. Because these two resistant cultigens were crossed to the same susceptible female, these data indicate that even though 'Slice' is more resistant than M 17, the cytoplasm of M 17 may contribute more to leaf resistance than the cytoplasm of 'Slice'. The same trend for these two crosses was apparent for stem rating also, but the $F_{1}$ and $F_{1}$ ' were not significantly different in either cross, even though the magnitudes of the differences were similar to those for leaf ratings. The failure to detect reciprocal differences in the $F_{1}$ generation for stem rating in these crosses may have been due to the smaller number of plants rated for stem lesions. No reciprocal differences were detected in the 'Homegreen \#2' X 'Wis. SMR 18' cross. Reciprocal differences for leaf rating in the 'Homegreen \#2' $x$ 'Marketmore 76' cross were detected in the $F_{1}$ generation but not in the $F_{2}$.

There are no other reports of cytoplasmic inheritance for any trait in cucumber and some inconsistencies are present in these results; therefore, interpretation of the current evidence for cytoplasmic inheritance should be withheld unless corroborated further .

Phenotypic correlations between leaf and stem ratings were moderate. The lack of high correlations between the two traits and the differing estimates of gene effects for the traits, suggest that leaf and stem resistance may be influenced, at least partially, by different genes.

Genetic gain for resistance to gummy stem blight should be low to moderate using the resistance found in 'Slice', 'Homegreen \#2', and M 17. Breeding methods, such as recurrent selection, which make the best use of additive variance should be used because much of the variance for resistance is additive. Also, methods with excellent environmental control should be used because environmental variation is as large or larger than additive variation. The possibility that cytoplasmic effects exist in cucumber should be investigated further, especially in the context of disease resistance.

\section{Literature Cited}

Dudley, J.W. and R.H. Moll. 1969. Interpretation and use of estimates of heritability and genetic variances in plant breeding. Crop Sci. 9:257-262.

Farr, D.F., G.F. Bills, G.P. Chamuris, and A.Y. Rossman. 1989. Fungi on plants and plant products in the U.S. Amer. Phytopath. Soc., St. Paul, Minn.

Gamble, E.E. 1962. Gene effects in corn (Zea mays L.): I. Separation and relative importance of gene effects for yield. Can. J. Plant Sci. 42:339-348.

Gordon, I.L., D.E. Byth, and L.N. Balaam. 1972. Variance of heritability ratios estimated from phenotypic variance components. Biometrics 28:401-415.

Hughes, G.R., C.W. Averre, and K.A. Sorensen. 1983. Growing pickling cucumbers in North Carolina. N.C. Agr. Ext. Serv. AG-315.

Lande, R. 1981. The minimum number of genes contributing to quantitative variation between and within populations. Genetics 99:541-553.

Mather, K. and J. L. Jinks. 1982. Biometrical genetics. Chapman and Hall, London.

Robinson, D.C., R.E. Comstock, and P.H. Harvey. 1955. Genetic variances in open pollinated corn. Genetics 40:45-60.

St. Amand, P.C. and T.C. Wehner. 1991. Crop loss to 14 diseases of cucumber in North Carolina from 1983 to 1988. Cucurbit Genet. Coop. Rpt. 14:15-17.

Svedelius, G. and T. Unestam. 1978. Experimental factors favoring infection of attached cucumber leaves by Didymella bryoniae. Trans. Brit. Mycol. Soc. 71:89-97.

Van Der Meer, Q.P., J.L. Van Bennekom, and A.C. Van Der Giessen. 1978. Gummy stem blight resistance of cucumbers (Cucumis sativus L.). Euphytica 27:861-864.

Van Steekelenburg, N.A.M. 1982. Factors influencing external fruit rot of cucumber caused by Didymella bryoniae. Neth. J. Plant Pathol. 88:47-56.

Warner, J. N. 1952. A method for estimating heritability. Agron. J. 44:427-430.

Wehner, T.C. and P.C. St. Amand. 1993. Field tests for resistance to gummy stem blight of cucumber in North Carolina. HortScience 28:327-329.

Wright, S. 1968. The genetics of qualitative variability. In: S. Wright, ed. Evolution and genetics of populations. vol. I. Genetic and biometric foundations. Univ. of Chicago Press, Chicago Ill.

Wyszogrodzka, A.J., P.H. Williams, and C.E. Peterson. 1986. Search for resistance to gummy stem blight (Didymella bryoniae) in cucumber (Cucumis sativus L.). Euphytica 35:603-613. 